\title{
Indian English Drama: Badal Sircar in Translation
}

Dhanya Johnson

Indian Drama in English translation has made daring innovations and prolific experiments in terms of both thematic concerns and technical virtuosities. It has been increasingly turning to history, legend, myth and folklore beating their springs of vivacity and choral cords of popularity with grand results. Plays written in various Indian languages are being translated into English and other languages as they are produced and appreciated in the various parts of the country. A closer contact is being established between the theatre workers from different regions and languages through these translations. Thus, regional drama in India is slowly paving a way for a 'national theatre' into which all streams of theatrical art seem to coverage. The major language theatres that are active all through the turbulent years of rejuvenation and consolidations are those of Hindi, Bengali, Marathi and Kannada.

The plays mentioned so far, both under the PreIndependence and the Post-Independence phase were originally written in English. Among the plays translated into English, there are a few, which were first written in the regional languages and subsequently translated into English by the authors themselves. Though, strictly speaking, these works cannot be called fully English plays, they can be mentioned under the topic, in view of the fact, that at least some of them are transcreations and not simply translations. Rabindranath Tagore, Mohan Rakesh, Badal Sircar, Vijay Tendulkar, and Girish Karnad have remained the most representative of the Indian English drama not only in Bengali, Hindi, Marathi and Kannada respectively but also on the panIndian level. 
The driving force behind the "third theatre" (alternate theatre or street theatre performed in villages as opposed to auditoriums), Badal Sirkar (15 July 1925 - 13 May 2011), popularly known as a 'barefoot playwright' for Bengali theatre was a legend. Through the seventies along with Girish Karnad(Kannada), Vijay Tendulkar(Marathi) and Mohan Rakesh (Hindi) Badal Sircar spearheaded the Indian playwriting movement providing with it some great masterpieces.

An influential Indian dramatist and theatre director he was a pioneering figure in street theatre as well as in experimental and contemporary Bengali theatre. Serving first as a popular proscenium playwright and director and then as an anonymous street theatre artist he prolifically wrote scripts for his Aanganmanch (courtyard stage) performances, and remains one of the most translated Indian playwrights. "The theatre of Badal Sircar", was described by Rustom Bharucha "as the most rigorously noncommercial political theatre in India". (Raustom Bharucha: 1993:127)

With the intention of enlightening the society, his plays reflected the atrocities that prevailed in the society and the decayed hierarchical system. He is also known for picking up ordinary people from ordinary life, who he feels, suit a particular role and gets them to act for his skits and plays. He depicts the existential attitude of modern man in the present times.

Badal Sircar, the great Bengali playwright uses contemporary situations and social problems to project the lifein-death attitude of modern life. The central theme of many of his early plays is a sense of utter meaninglessness in our existence, which leads to a state of metaphysical anguish. This anguish is in fact closely embedded in the Bengali middle-class psyche, the tearing up of which was Sircar's constant concern since his early theater career.

Sircar started his dramatic career with some comedies Translation Today 
and came to the limelight in 1965 with his celebrated Evam Indrajit. The unique structure of the play and the social utility of its theme drew an immediate attention of all concerned, and won widespread reputation through its translation into several languages including English. It is clearly existential. Like Beckett's play, Waiting for Godot, it makes clear that our existence is "a pointless particle of dust".

Emotions are excluded as meaningless property and the external world is reduced to an unreal and weightless existence. The play makes the point that "nothing worth mentioning ever happens". As Satyadev Dubey rightly observes, Evam Indrajit is about the residue of the middle class "who have failed to adjust, align and ceased to aspire and also those who are enmeshed in the day-today struggle for survival".

Evam Indrajit is a tale of a playwright who struggles painfully in vain to write a play. As he, furiously tears up his manuscripts, his inspiration appears as a woman whom the dramatist calls Manasi. The writer is not able to write a play, because as a conscientious and honest artist, he finds that life is too chaotic and fragmentary to cohere into dramatic mould and too mechanical to have any meaning. His agony is the agony of the artist who is deeply aware of the sterility and horror of life. Badal Sircar, like T. S. Eliot in The Waste Land, offers no hope. The protagonist of the play ultimately meets with only despair, the keynote which is struck at the beginning itself. Satyadev Dubey, in his introduction to Evam Indrajit, praises the play as a milestone in the history of modern Indian drama. The play provided for theatre practitioners all over India the shock of recognition. Badal Sircar shook off all the conventions of the traditional drama by this play.

The subsequent plays by Sircar focus on various aspects of modern life, ranging from man-woman relationship to social and political evils. These include The Mad Horse, The Whole Night, Procession, Bhoma, Stale News, Circle, The Pleasant History of India and others. The chief characteristics of Sircar's plays are 
choice of the middle class people as characters in the drama, revelation of the hidden social and moral evils, an attempt to remove the complacence of the people and a change in the dramatic technique. Badal Sircar has also portrayed a realistic picture of contemporary society. The problems of population growth, unemployment, poverty, and child labour are presented dramatically. The ills of the society are also ruthlessly satirized. Along with Spartacus, Sircar's later plays Procession (1972), Bhoma (1974), and Stale News (1980) are based on the concepts of third theatre. Procession is one of his most intricately structured plays with innumerable transactions and juxtapositions. These plays have placed him on a pedestal higher than other contemporary playwrights of Indian drama. Through these three typical plays, one can see the realization of Sircar's philosophy and vision of making people aware of their social responsibility. He makes theatre a medium of conveying individual responsibility of the people towards the society.

Sircar's Procession is about the search for a "real" home - a new society based on equality. It is about a new society where man does not have to live by exploiting man and where each works according to his ability and gets according to his needs. His Bhoma is a dramatization of a life of the oppressed peasant in Indian rural society. It presents his social and economical exploitation through a series of scenes. A conscientious playwright not only presents the gravity of the problem but also offers a solution by employing powerful symbols and images. The society, full of opportunists and exploiters, is presented as a forest of poisonous trees and Bhoma, an aboriginal barbarian as a woodcutter. Bhoma is an archetype of the oppressed exploited peasant who, finally takes up his "rusty axe", grinds and sharpens it to cut the poisonous trees that grow around him. These three plays are based on the concept of the Third Theatre.

Stale News deals with the theme of revolt. It centres round a young man who is bombarded with shattering information full of contradictions and contrasts, which come to him as "stale news". 
However, he becomes aware through the inspiring guidance of the Dead Man of the pathetic conditions of the poor and the need for social reform. The young man is not ready to come out of the strange hold of the traditional, routine life and develop a sense of commitment so as to revolt against the social and economic justice.

It is through his form "Third Theatre" Sircar makes the society especially, the middle class, and feels guilty for being indifferent towards man and his problems. The characters in his plays are not individualized used at all. They can be seen as what Sircar himself has said, "I can be taken as a prototype of a particular class in a society at a particular period".

Badal Sircar's Some Day Later (Pare Konodin) is a complex interviewing of the realistic and the fantastical modes. Time is broken up so that the present as seen in the play is already past time to some of the characters. The play raises several questionsWhat is history? How would a change in a historical process affect the present? What is the relation of the present to the past? The answer is not given in intellectual terms but through the felt experience of the central character Shankar. The play opens and closes on a darkened stage with the tortured voice of Shankar asserting his determination to speak, to write, to tell all, so that some later day the horror of his experience may not have to be repeated. Suspense is cleverly interwoven as the play unfolds. The playwright's method of juxtaposing the real and the fantastic serves to further irony. Human beings, with their ordinary concerns- property, career, and marriage- are merely puppets in the inexorable cycle of historical process. Thus, the human condition is "absurd" and can arouse only compassion. On the other hand, it can also arouse laughter. In fact, laughter becomes a means by which men can face the realities of their existence. According to him, comedy does not rank low in the dramatic categories. Comedy does not have a message, it does not discuss social problems, it does not voice opinions- even if one accepts these premises, still laughter does not lose its value in his 
estimation. He further writes that people can laugh in the midst of greatest sorrow, they can heighten the profoundest tragedy through laughter; deal with the most complex problems through laughter. That is why he does not undervalue the importance of laughter. His play Poet's Story (Kobi Kahini) is a suave comedy on a contemporary theme- an election campaign. It centres round the problems of Manibhushan as he sets about the task of winning a seat to the Assembly. The play makes use of one of the most conventional devices of comedy- the mistaken identity theme. Sircar directs his witty barbs at personal foibles as well as social aberrations. Sircar laughs at a society where an Honours degree in literature can be had by memorizing a few standard texts, where a more meaningless a poem is, the more it is admired. The laughter becomes more mocking when it is directed at the underhand means employed by politicians to gain their selfish ends. The play succeeds eminently in its aim of holding up a mirror to society.

An important aim of Badal Sircar's comedies is almost missionary dedication to the cause of social change and his use of theatre to highlight the ideal by exposing the gap between the ideal and the real. He worked to change the contents of his plays drastically. His plays, belonging to the Third Theatre were powerful responses to the various socio-political realities he encouraged. These plays show Sircar's deeper understanding of the problems of the nuclear age and the poverty, corruption, greed and the industrial and agricultural exploitation of the poor. Contemporary issues are what make street plays succeed. Perennial issues like communalism, terrorism, police brutality, bride burning, dowry system, caste inequalities, industrial and agricultural exploitation, health care and alcoholism are included in their repertory. "Street theater has become an important tool to promote awareness in the minds of people on topical and perennial issues".

Badal Sircar is among the three great contemporary writers - Karnad, Tendulkar and Rakesh. He delves deep into the problems of middle-class society. He uses contemporary situations to project the existential attitude of modern life.

\section{Translation Today}


Popularly known as a 'barefoot playwright', he stands in the forefront of a new theatrical movement in India. He has created a genuine people's theatre known as Third Theatre, supported and created by the people and not merely performed by the people. Sircar's professional career as an urban planner, his training as a civil engineer, is mixed with his inner life as a playwright and its outward expression in his role as a theatre director and actor. His uncompromising attitude to social evils shows his link with his contemporaries. The distinctive qualities of his plays, which go by the name of 'Third Theatre', lie in their appeal to the mind of the audience. Here lies his success as a playwright. Sircar is one of the brightest stars in the constellation of Indian Drama. His plays prove that Post-Independence Drama has made a fresh ground both technically and thematically.

\section{REFERENCES}

Bharuch, Rustam, 1993. Rehearsals of Revolution: The Political Theatre of Bengal Honolulni: University of Hawai Press.

Breisach, Ernst, 1962. Introduction to Modern Existentialism. New York: Grove Press.

Camus, Albert, 1954. The Stranger. Translated. Stuart Gilbert. New York: Vintage Books.

Kafka, Franz, 1986. The Metamorphosis. Translated. Stanley Corngold. New York: Bantam Books.

Karnad, Girish, 1974. Ebam Indrajit. English Description Calcutta: Oxford University Press.

Lal, Ananda, 2009. Oxford Companion to Indian Theatre. New Delhi: Oxford press.

"Badal Sarkar" criterion.18 April 2012. < http://www.the-criterion. com The Criterion: An International Journal in English/ badal sarkar> 